\title{
Manajemen Pemberian Pakan Sapi Bali
}

\author{
Ervina Wahyuni dan Muh. Amin \\ Program Studi Peternakan, Universitas Muslim Maros \\ e-mail: aminlebah@gmail.com
}

\begin{abstract}
The main things that need to be considered to ensure the sustainability and continuity of the livestock business are breeding (seeds/feeders), feeding (feed), and management, which are interrelated and complementary. This study aimed to understand the method of cattle fattening in Enhal Farm, especially the management of feed on beef cattle farms run at Enhal Farm. This study started from 15 May to 15 June 2020 in the bali cattle fattening business, Enhal Farm, Tombolo Hamlet, Tompobulu Village, Tompobulu sub-district, Maros regeny. The study focuses on Bali cattle feeding management which includes the type of feed given, mixing feed, how to get feed, the amount of feed, the frequency of feeding, how to feed and provide drinking water. The forage provided at Enhal Farm is in the form of elephant grass and rice straw, while the concentrate is a mixture of several feed ingredients such as fermented straw (such as corn cobs, bran, molasses, coconut cake, mineral mix, salt). The provision of forage in the form of elephant grass and rice straw is also based on the weight of the cows, the ability of the cows to consume rations, measured in the form of dry matter. The higher the body weight of the cow, the lower the percentage of its ability to consume dry rations. Drinking water is given ad libitum.
\end{abstract}

Keywords: Cattle, Fattening, Feed

\begin{abstract}
ABSTRAK
Hal pokok yang perlu diperhatikan untuk menjamin keberlangsungan dan kontinuitas usaha peternakan yaitu breeding (bibit/bakalan), feeding (pakan), dan management (manajemen), yang saling terkait satu sama lain dan saling melengkapi. Studi ini bertujuan untuk memahami metode penggemukan sapi di Enhal farm khususnya manajemen pemberian pakan pada peternakan sapi potong yang dijalankan di Enhal Farm. Studi ini dimulai dari tanggal 15 mei sampai dengan 15 juni 2020 di usaha peternakan penggemukan sapi bali Enhal farm Dusun Tombolo, Desa Tompobulu, Kecamatan Tompobulu, Kabupaten Maros. Studi berfokus pada manajemen pemberian pakan sapi bali yang meliputi jenis pakan yang diberikan, pencampuran pakan, cara memperoleh pakan, jumlah pemberian pakan, frekuensi pemberian pakan, cara pemberian pakan dan pemberian air minum. Pakan hijauan yang diberikan di Enhal Farm berupa rumput Gajah dan jerami padi, sedangkan konsentrat berupa campuran dari beberapa bahan pakan seperti jerami fermentasi (seperti tongkol jagung, dedak, molases, bungkil kelapa, mineral mix, garam). Pemberian pakan hijauan berupa rumput gajah dan jerami padi juga didasarkan berat badan sapi kemampuan sapi dalam mengonsumsi ransum diukur dalam bentuk bahan kering. Semakin tinggi bobot badan sapi akan semakin menurun persentase kemampuannya mengonsumsi bahan kering ransum. Air minum diberikan secara ad libitum.
\end{abstract}

Kata Kunci: Sapi, Penggemukan, Pakan 


\section{PENDAHULUAN}

Usaha penggemukan sapi potong saat ini mempunyai kencenderungan makin berkembang. Hal ini ditandai dengan semakin banyaknya masyarakat di daerah yang mengusahakan penggemukan sapi. Prospek usaha penggemukan sapi potong cukup menguntungkan terbukti dari kebutuhan akan konsumsi daging sapi setiap tahun selalu meningkat. Sementara itu pemenuhan akan kebutuhan daging masih kurang, dengan kata lain permintaan daging sebagai konsumsi terus bertambah. Tiga hal pokok yang perlu diperhatikan agar dapat menjadi peternak sukses sehingga kelangsungan usaha ternak tersebut dapat berjalan yaitu breeding (bibit/bakalan), feeding (pakan), dan management (manajemen), yang saling terkait satu sama lain dan saling melengkapi.

Studi ini bertujuan untuk memahami metode penggemukan sapi di Enhal farm khususnya manajemen pemberian pakan pada peternakan sapi potong yang dijalankan di Enhal Farm. Pakan merupakan salah satu faktor yang sangat penting dalam suatu usaha penggemukan sapi potong. Pemberian nutrisi yang bagus diiringi dengan strategi manajemen yang baik dapat meningkatkan produktivitas sapi Bali (Heryanto et al, 2016). Pakan yang diberikan untuk sapi potong dapat dibedakan menjadi dua macam, yaitu pakan hijauan dan pakan konsentrat (Erlangga, 2013). Oleh karena itu bibit sapi yang baik harus diimbangi dengan pemberian pakan yang baik pula dan cukup memenuhi kebutuhan nutriennya. Adapun fungsi lain dari pakan adalah untuk mempertahankan daya tahan tubuh dan kesehatan. Produktivitas ternak sapi potong sangat peka atau sensitif terhadap perubahan pemberian pakan, oleh karena itu pakan yang diberikan harus sesuai dengan ketersediaan, kesinambungan mutu maupun jumlahnya, Menurut Yulianto
(2012), bahwa pemberian pakan hijauan pada penggemukan sapi tidak akan memberikan pengaruh yang signifikan terhadap pertambahan berat badan yang tinggi dalam waktu yang singkat. Disamping itu perlu diketahui bahwa biaya pakan dalam usaha penggemukan memberikan konstribusi yang cukup besar.

Pada dasarnya, sumber pakan sapi dapat disediakan dalam bentuk hijauan dan konsentrat, dan yang terpenting adalah pakan harus memenuhi kebutuhan protein, karbohidrat, lemak, dan vitamin serta mineral. Yulianti (2012), menyatakan, bahwa penambahan konsentrat pada sapi bertujuan untuk meningkatkan nilai pakan dan menambah energi. Tingginya pemberian pakan berenergi menyebabkan peningkatan konsumsi dan daya cerna dari rumput atau hijauan kualitas rendah. Secara alamiah pakan utama ternak sapi baik potong maupun perah adalah hijauan, dapat berasal dari rumput alam atau lapang, rumput unggul, leguminosa dan limbah pertanian serta tanaman hijauan lainnya. Dalam pemberiannya harus diperhatikan hijauan tersebut disukai ternak dan tidak mengandung racun atau toxin sehingga dapat membahayakan perkembangan ternak yang mengkonsumsi. Namun permasalahan yang ada bahwa hijauan di daerah tropis seperti di wilayah Indonesia mempunyai kualitas yang kurang baik sehingga untuk memenuhi kebutuhan gizi ternak tersebut, perlu ditambah dengan pemberian pakan konsentrat

Dalam pemberian pakan di kandang atau di palungan, yang perlu diperhatikan adalah mengetahui berapa jumlah pakan dan bagaimana ransum yang diberikan pada ternak sapi. Studi ini lebih lanjut akan menjabarkan tetang feeding standard yang tepat dan efisien untuk kegiatan penggemukan sapi potong. 


\section{METODE}

Studi ini dilaksanakan pada bulan Maret 2020 di usaha peternakan penggemukan sapi bali Enhal farm Dusun Tombolo, Desa Tompobulu, kec.Tompobulu, kab. Maros.

Studi berfokus pada manajemen pemberian pakan sapi bali yang meliputi jenis pakan yang diberikan, pencampuran pakan, cara memperoleh pakan, jumlah pemberian pakan, frekuensi pemberian pakan, cara pemberian pakan dan pemberian air minum.

Teknik pengumpulan data yang digunakan adalah pengamatan (observasi), wawancara dan pemeliaraan sapi Bali. Pengamatan dilakukan secara langsung terhadap kegiatan yang berhubungan dengan pelaksanaan operasional perusahaan guna memperoleh informasi dan pengalaman langsung. Wawancara dilakukan dengan mengadakan tanya jawab secara langsung dengan responden. Responden yang dimaksud dalam penelitian ini adalah pimpinan Enhal farm, karyawan kandang. Pemeliharaan sapi yang dilakukan meliputi pembersihan Kandang, pemberian pakan dan air minum, pengambilan rumput gajah, pemotongan rumput gajah, Pemberian obat cacing dan vitamin serta pembuatan Silase

\section{HASIL DAN PEMBAHASAN}

\section{Pakan}

Pada dasarnya, sumber pakan sapi dapat disediakan dalam bentuk hijauan dan konsentrat . Menurut Dicky P (2011), salah satu yang menyebabkan rendahnya tingkat konsumsi pakan oleh ternak adalah faktor palatabilitas pakan. Ternak memerlukan waktu lama beradaptasi baik terhadap pakan, lingkungan kandang, pekerja maupun lingkungan. Sumber pakan di peternakan Enhal farm sudah memenuhi untuk usaha penggemukan sapi potong. Pakan hijauan yang diberikan berupa rumput
Gajah dan jerami padi, sedangkan konsentrat berupa campuran dari beberapa bahan pakan seperti jerami fermentasi (dedak, tongkol jagung, tetes tebu).

Dalam usaha penggemukan sapi potong, pemberian pakan ditujukan untuk memenuhi kebutuhan hidup pokok dan produksi. kebutuhan hidup pokok sangat tergantung dari bobot badan ternak, yaitu semakin berat bobot badan ternak maka semakin tinggi jumlah kebutuhan pakannya, sedangkan kebutuhan Lokasi kandang cukup strategis karena dekat dengan jalan sehingga mempermudah transportasi. Lokasi kandang membujur dari arah utara ke selatan dengan bentuk atap kandang tertutup yang menggunakan bahan seng. Karena harga relatif murah, mudah didapat, tahan lama dan dapat menahan panas matahari dengan baik, sehingga tidak langsung mempengaruhi panas ruangan kandang. Sebagian kandang yang terbuka yaitu pada bagian ventilasi. Sehingga sinar matahari tetap dapat masuk ke kandang dan ventilasi udara tidak terhambat sinar matahari, terutama pada pagi hari, harus dapat masuk secara langsung ke dalam kandang. Karena sinar ultraviolet sangat baik untuk membunuh kuman-kuman penyakit yang hidup di dalam kandang. Bangunan kandang ada 3 buah yang masing-masing kandang berkapasitas 6 ekor. Lantai dari semen dengan kemiringan \pm 30 , hal ini dimaksudkan agar feses atau urine dapat mengalir mudah ke tempat pembuangan limbah. Setiap petak kandang dilengkapi dengan tempat pakan dan tempat minum. Kandang yang ada termasuk kandang individu, dengan sistem head to head atau saling berhadapan. Tempat pakan ditempatkan pada sisi depan kandang dan berdampingan dengan tempat minum memanjang dari kandang

\section{Jenis pakan}

Perusahaan peternakan penggemukan sapi bali Enhal farm dalam 
memenuhi kebutuhan pakan yang diberikan pada ternak memanfaatkan limbah pertanian atau limbah industri pertanian yang tidak dikonsumsi oleh manusia. Pakan yang digunakan berupa hijauan dan konsentrat. Hijauan yang digunakan berupa hijauan segar dan kering. Hijauan segar yang diberikan berupa rumput gajah karena hijauan segar mempunyai kandungan vitamin dan mineral yang diperlukan tubuh ternak. Sedangkan hijauan kering berupa jerami padi. Jerami padi diberikan dalam bentuk jerami fermentasi. Karena pemberian pakan jerami padi dimaksudkan untuk memenuhi kebutuhan pakan sumber serat dan menimbulkan rasa kenyang. Jerami padi merupakan limbah pertanian yang cukup potensial sebagai pakan ternak karena tersedia cukup banyak dan mudah diperoleh disekitar daerah ternakan.

Pemberian jerami padi di Enhal farm diberikan dalam bentuk jerami padi fermentasi. Proses pembuatan jerami padi fermentasi dengan menggunakan molases. molases berfungsi untuk memperbaiki nilai gizi jerami padi dan menambah aroma harum pada pakan fermentasi. Antonius (2010) juga mengemukakan bahwa fermentasi jerami dengan menggunakan MOL diharapkan mampu merombak dan merenggangkan ikatan lignoselulosa dan lignohemisellulosa, sehingga jerami lebih mudah dicerna oleh mikroba rumen.

Pakan konsentrat yang digunakan berupa konsentrat campuran yang terdiri dari jerami fermentasi yang terbuat dari beberapa bahan pakan ( seperti tongkol jagung, dedak, molases, bungkil kelapa, mineral mix, garam ), Pencampuran bahan pakan lebih murah penggunaannya lebih banyak, hal ini bertujuan untuk menghemat biaya pakan tanpa harus mengurangi nutrien yang dibutuhkan oleh ternak.

\section{Cara memperoleh pakan}

Pakan hijauan berupa rumput gajah diperoleh dari areal perkebunan sendiri, sedangkan untuk jerami padi diperoleh dari lokasi persawahan yang berada di sekitar peternakan. Jerami padi yang diberikan adalah jerami padi fermentasi yang menggunakan tetes tebu.

\section{Jumlah pemberian pakan}

Pemberian pakan di Enhal farm berupa konsentrat dan hijauan. Pemberian pakan hijauan berupa rumput gajah dan jerami padi juga didasarkan berat badan sapi kemampuan sapi dalam mengonsumsi ransum diukur dalam bentuk bahan kering. Semakin tinggi bobot badan sapi akan semakin menurun persentase kemampuannya mengonsumsi bahan kering ransum. Pada usaha penggemukan sapi potong Di Enhal farm pemberiaan pakannya sudah cukup karena diberikan sebesar 10\% dari BB sapi (Yulianto, P. 2012) . Dari beberapa sapi dapat diketahui bahwa rata - rata pemberian pakan sudah sesuai \% dari berat badan sapi. Jumlah kebutuhan hasian Sapi di Peternakan Enhal Farm terinci pada Tabel 1.

\section{Frekuensi pemberian pakan}

Pemberian konsentrat dapat dilakukan dua atau tiga kali dalam sehari semalam. Pemberian konsentrat dua kali dalam sehari semalam dapat dilakukan pada pagi hari sekitar pukul 06.00 dan sekitar pukul 13.00. Lain lagi dengan pemberian yang dilakukan tiga kali dalam sehari semalam pada saat pukul 09.00, sekitar pukul 15.00, dan sekitar pukul 19.00. sedangkan pemberian hijauan dilakukan sekitar 2 jam setelah pemberian konsentrat. Pemberian hijauan ini dilakukan secara bertahap dan minimal 2 kali dalam sehari semalam. Frekuensi pemberian hijauan yang lebih sering dilakukan dapat meningkatkan kemampuan sapi itu untuk mengonsumsi ransum dan juga meningkatkan kencernaan bahan kering hijauan

Teknik pemberian pakan yang baik untuk mencapai pertambahan bobot badan yang lebih tinggi pada penggemukan sapi potong adalah dengan mengatur jarak waktu antara 
pemberian konsentrat dengan hijauan. Pemberian konsentrat dapat dilakukan dua atau tiga kali dalam sehari semalam. Frekuensi pemberian hijauan yang lebih sering dilakukan dapat meningkatkan kemampuan sapi itu untuk mengonsumsi ransum dan juga meningkatkan kencernaan bahan kering hijauan, peningkatan kecernaan bahan kering ransum akan menambah jumlah zat-zat gizi yang dapat dimanfaatkan untuk produksi, termasuk pertumbuhan (Siregar, 2018). Frekuensi pemberian pakan di Enhal Farm dijabarkan pada Tabel 2.

Tabel 1. Jumlah kebutuhan harian Sapi di peternakan Enhal farm

\begin{tabular}{ccc}
\hline Sapi & $\begin{array}{c}\text { BBH } \\
\text { (Berat Badan Harian) }\end{array}$ & $\begin{array}{c}\text { Kebutuhan Harian } \\
(\mathrm{Kg})\end{array}$ \\
\hline P. 1 & $101.8 \times 10 \%$ & 10.18 \\
P. 2 & $244.6 \times 10 \%$ & 24.46 \\
P. 3 & $159.0 \times 10 \%$ & 15.9 \\
P. 4 & $105.6 \times 10 \%$ & 10.5 \\
P. 2.1 & $98.6 \times 10 \%$ & 9.86 \\
P.2.2 & $287.2 \times 10 \%$ & 28.72 \\
P.2.3 & $122.2 \times 10 \%$ & 12.22 \\
P. 2.4 & $178.2 \times 10 \%$ & 17.82 \\
P. 0.1 & $314.8 \times 10 \%$ & 31.4 \\
P. 0.2 & $181.6 \times 10 \%$ & 18.16 \\
P. 0.3 & $140.4 \times 10 \%$ & 14.04 \\
P. 0.4 & $91.2 \times 10 \%$ & 9.12 \\
\hline
\end{tabular}

\section{Frekuensi pemberian pakan}

Pemberian konsentrat dapat dilakukan dua atau tiga kali dalam sehari semalam. Pemberian konsentrat dua kali dalam sehari semalam dapat dilakukan pada pagi hari sekitar pukul 06.00 dan sekitar pukul 13.00. Lain lagi dengan pemberian yang dilakukan tiga kali dalam sehari semalam pada saat pukul 09.00, sekitar pukul 15.00, dan sekitar pukul 19.00. sedangkan pemberian hijauan dilakukan sekitar 2 jam setelah pemberian konsentrat. Pemberian hijauan ini dilakukan secara bertahap dan minimal 2 kali dalam sehari semalam. Frekuensi pemberian hijauan yang lebih sering dilakukan dapat meningkatkan kemampuan sapi itu untuk mengonsumsi ransum dan juga meningkatkan kencernaan bahan kering hijauan

Teknik pemberian pakan yang baik untuk mencapai pertambahan bobot badan yang lebih tinggi pada penggemukan sapi potong adalah dengan mengatur jarak waktu antara pemberian konsentrat dengan hijauan. Pemberian konsentrat dapat dilakukan dua atau tiga kali dalam sehari semalam. Frekuensi pemberian hijauan yang lebih sering dilakukan dapat meningkatkan kemampuan sapi itu untuk mengonsumsi ransum dan juga meningkatkan kencernaan bahan kering hijauan, peningkatan kecernaan bahan kering ransum akan menambah jumlah zat-zat gizi yang dapat dimanfaatkan untuk produksi, termasuk pertumbuhan (Siregar, 2018). Frekuensi pemberian pakan di Enhal Farm dijabarkan pada Tabel 3.

\section{Pemberian air minum}

Kebutuhan air minum untuk ternak sapi didasarkan pada kebutuhan sapi itu sendiri. Air minum sebaiknya disediakan sesaat sebelum makan untuk menghindari terjadinya kembung perut. Air minum diberikan secara ad libitum, 
dimana ketersediaannya tidak pernah kurang bagi ternak.

Kebutuhan air minum untuk sapi di Enhal farm terpenuhi karena air minum diberikan secara ad libitum. Kebutuhan air untuk kebutuhan ternak baik untuk air minum maupun kebersihan kandang bersumber dari sumur bor yang kemudiaan ditampung ke dalam bak penampungan air.

Tabel 2. Frekuensi pemberian pakan

\begin{tabular}{cl}
\hline Jam & \multicolumn{1}{c}{ Frekuensi Pemberian Pakan } \\
\hline $06: 00$ & Membersihkan tempat pakan \& minum dari sisa semalam \\
$07: 00$ & Memberikan jenis pakan penguat (konsentrat) $50 \%$ \\
09:00 & Memberikan jenis pakan serat kasar (rumput gajah) $40 \%$ \\
$13: 00$ & Memberikan jatah konsentrat kering sisa 50\% \\
$15: 00$ & Memberikan jatah serat kasar sisa $60 \%$ \\
$19: 00$ & Memberikan pakan jenis serat, jerami padi kering, jatahnya $1-3$ \\
& kg/ekor untuk sapi dengan bobot badan 400 kg/ekor. \\
\hline
\end{tabular}

\section{PENUTUP}

\section{Kesimpulan}

Berdasarkan hasil praktek kerja lapangan dapat disimpulkan, bahwa pada dasarnya manajemen penggemukan sapi potong di Enhal farm sudah cukup baik. Sumber pakan di peternakan Enhal farm sudah memenuhi untuk usaha penggemukan sapi potong. Pakan hijauan yang diberikan berupa rumput Gajah dan jerami padi, sedangkan konsentrat berupa campuran dari beberapa bahan pakan seperti jerami fermentasi ( seperti tongkol jagung, dedak, molases, bungkil kelapa, mineral mix, garam ). Proses pembuatan jerami padi fermentasi dilakukan dengan menambahkan molases. Molases berfungsi untuk memperbaiki nilai gizi jerami padi dan menambah aroma harum pada pakan fermentasi. Fermentasi jerami dengan menggunakan molases diharapkan mampu merombak dan merenggangkan ikatan lignoselulosa dan lignohemisellulosa, sehingga jerami lebih mudah dicerna oleh mikroba rumen.

\section{Saran}

Sebaiknya dibuat kandang karantina untuk ternak baru, sehingga dapat mengantisipasi terjadinya penularan bibit penyakit yang dibawa oleh sapi. Di peternakan Enhal Farm tidak dilakukan karantina untuk ternak-ternak baru sehingga memungkinkan terjadi perpindahan penyakit dari ternak yang baru dikandangkan dengan ternak yang telah dipelihara lebih dahulu.

\section{DAFTAR PUSTAKA}

Antonius. 2010. Pengaruh pemberian jerami padi terfermentasi terhadap palatabilitas kecernaan serat dan Digestible Energy ransum sapi. Prosiding Seminar Nasional Teknologi Peternakan dan Veteriner. Bogor, 3-4 Agustus 2010. Bogor (Indonesia): Puslitbangnak. hlm. 224-228.

Dicky Pamungkas, Y.N. Anggraeny, Kusmartono, Hartutik, S. Quigley dan D.P. Poppi. 2011. Penggunaan Daun Lamtoro (L. leucocephala) Dalam Ransum Terhadap Konsumsi, Kecernaan Dan Pertambahan Bobot Badan Sapi Bali Jantan Lepas Sapih. Seminar Nasional Teknologi Peternakan dan Veteriner 2011. (diakses 4 juli2 2020)

Erlangga, E. 2013. Meningkatkan Bobot Sapi Potong dengan Pakan Racikan Sendiri. Pustaka Argo Mandiri.Pamulang. 
Heryanto K., Maaruf, S.S., Malalantang., Waani M.R. 2016. Pengaruh Pemberian Rumput Raja (Pennisetum Purpupoides) dan Tebon Jagung terhadap Performans Sapi Peranakan Ongole (Po) Betina. Jurnal Zootek Vol. 36 No.1:123-130.

Siregar. 2018. Ransum Ternak Ruminansia.Jakarta: Penebar Swadaya.
Yulianti.H. 2012. Laporan Praktikum Penggunaan UMB. (https:// wordpress.com/2008/10/pakanternak-bag2.doc). (diakses 4 juli2 2020)

Yulianto, P. 2012. .Penggemukan Sapi Potong. Penebar Swadaya. Jakarta. (diakses 4 juli2 2020) 